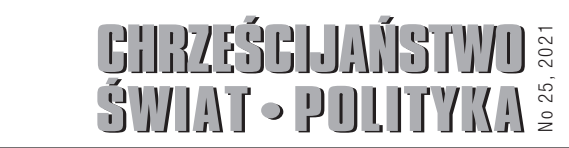

ZESZYTY SPOŁECZNEJ MYŚLI KOŚCIOŁA

\author{
Aniela Dylus
}

Uniwersytet Kardynała Stefana Wyszyńskiego w Warszawie, Polska

\title{
Pomocniczość \\ w koncepcji społecznej gospodarki rynkowej
}

\begin{abstract}
Abstrakt: W artykule została opisana kompleksowo zasada pomocniczości znana również pod nazwą: subsydiarność i jej roli we współczesnym modelu gospodarki jakim jest Społeczna Gospodarka Rynkowa. Zasada pomocniczości wpierw wypływa z przyjętych zasad etycznych takich jak wolność i sprawiedliwość. Dopiero przy takim założeniu można rozważać jej rolę, także w modelu Społecznej Gospodarki Rynkowej. Tekst podejmuje zagadnienie roli pomocniczości w porządku państwowym i gospodarczym a także aktualność tej myśli.
\end{abstract}

Słowa kluczowe: katolicka nauka społeczna, społeczna gospodarka rynkowa, subsydiarność, zasada pomocniczości

\begin{abstract}
The article comprehensively describes the principle of subsidiarity and its role in the contemporary model of the economy, which is the Social Market Economy (SOME). The principle of subsidiarity first builds upon adopted ethical principles such as freedom and justice. Only with such an assumption can its role be considered, also in the model of the Social Market Economy. The text deals with the role of subsidiarity in the state and economic order as well as the relevance and topicality of this concept.
\end{abstract}

Keywords: Catholic social teaching, social market economy, (principle of) subsidiarity

\section{Wprowadzenie}

Uzasadniając określony tytułem wybór tematu tego tekstu przypominam, że społeczna gospodarka rynkowa (SGR) to koncepcja „współczesna”. Została opracowana teoretycznie przez ordoliberałów ze szkoły fryburskiej w latach 30. XX wieku oraz wdrożona przez Ludwiga Erharda w powojennych Niemczech w oparciu o program 
opracowany głównie przez Alfreda Müllera-Armacka. Jako jej początek przyjmuje się reformę walutową z 20 czerwca 1948 r. Ten nadreński model „społecznie oswojonego kapitalizmu" (J. Schumpeter) w różnych wersjach i odcieniach przejęly następnie niektóre państwa europejskie (np. Austria, Szwajcaria, Belgia, częściowo - Francja) oraz Unia Europejska. Również podstawę ustroju gospodarczego Polski - zgodnie z art. 20 konstytucji z 1997 r. - stanowi właśnie SGR.

Nie zamierzam tu omawiać całego fundamentu aksjologicznego koncepcji SGR. Wybieram jedną tylko ideę przewodnią - pomocniczości. Z perspektywy metateoretycznej uznawana jest ona jako norma, a nawet zasada społeczna, a także jako pewna wartość. W etyce przyjmuje się przecież równoważność wartości i norm. Na straży domagających się realizacji wartości stoją bowiem określone normy. Zdaję sobie także sprawę, że element „społeczny” koncepcji SGR kojarzy się raczej z solidarnością, społecznym wyrównywaniem. Uważam jednak, że subsydiarność jest jeszcze bardziej charakterystycznym „znakiem firmowym” tego modelu. Niekiedy SGR wręcz definiuje się jako „gospodarkę rynkową bazującą na subsydiarności”". Zasługuje na uwagę również dlatego, że właśnie twórcy SGR - ordoliberałowie nadali „współczesny wyraz idei subsydiarności” [por. Delsol 1996: 49]. Oczywiście, nie da się jej wyizolować z pozostałych idei przewodnich, będących fundamentem SGR.

Ponieważ ordoliberałowie traktowali zasadę pomocniczości jako ściśle związaną z określonym obrazem człowieka, odtworzenie ich koncepcji antropologicznej (1), a także miejsca pomocniczości wśród idei przewodnich SGR (2) poprzedzać będzie dalsze rozważania. Okazuje się, że kluczowa dla koncepcji SGR kategoria ładu (ordo) została opracowana m.in. właśnie w nawiązaniu do pomocniczości (3). Podobne nawiązania odkrywamy zarówno przy tworzeniu gospodarczego "porządku ramowego", co jest głównym celem polityki gospodarczej (4), jak i w trakcie aktywności „państwa społecznego” przy prowadzeniu pomocniczej polityki społecznej (5). Zwieńczeniem niniejszej refleksji będzie odpowiedź na pytanie o aktualność pomocniczości wpisanej w SGR (6).

\section{Antropologiczny fundament SGR}

Nie da się adekwatnie poznać i ocenić żadnej koncepcji ekonomicznej i odpowiadającego mu systemu gospodarczego bez odkrycia ich antropologicznych fundamentów. Jaki zatem obraz człowieka zakłada się w systemie SGR?

${ }^{1}$ Por. tytuł tekstu U. Nothelle-Wildfeuer: Soziale Marktwirtschaft als subsidiaritätsbasierte Marktwirtschaft. 
Już nazwa „ordoliberalizm” na określenie szkoły (fryburskiej), która opracowała teoretyczny fundament SGR świadczy, że jej przedstawiciele generalnie przyznawali się do liberalizmu. Pojmowali go przy tym, jak np. Wilhelm Röpke, jako „prawowite dziecko chrześcijaństwa”, ukierunkowane humanistycznie, personalistycznie, antyautorytarnie i uniwersalistycznie [1950: 18 za Franco 2018: 268]. Taki liberalizm był oczywiście daleki od leseferystycznego XIX-wiecznego tzw. „paleoliberalizmu”. Zdecydowanie odcinał się od charakterystycznego dla niego obrazu człowieka - homo oeconomicus, czyli w pełni wolnego, rozsądnego egoisty, skoncentrowanego na zabieganiu o interes własny ${ }^{2}$.

Natomiast ordoliberalizm, uznając konieczność zakotwiczenia rynku w ramy moralne i instytucjonalne, $\mathrm{w}$ centrum stawiał godność i wolność człowieka pojmowanego jako osoba. Formuła Wilhelma Röpke „gospodarka w służbie człowieka” [1937/1979: 332-334 za Franco 2018: 269] dobrze oddaje „ekonomiczny humanizm” tego specyficznego liberalizmu, nie izolującego się od społeczno-politycznego kontekstu i usiłującego powiązać ze sobą wolność człowieka z jego wymiarem społecznym - z odniesieniem wspólnotowym [1957/1964 za Franco 2018: 269]. Człowiek nie był tu ujmowany jednowymiarowo. W identyfikacji jego natury uwzględniano i potrzeby materialne, i niematerialne. Jest on całością, obejmującą także wymiar moralny, duchowy i religijny. Jest otwarty na transcendencję i pytania religijne.

Dla ojców założycieli SGR godność człowieka była najwyższym normatywnym kryterium. To od niej uzależnione były prawa i mechanizmy ekonomiczne. W świetle kryterium godności oceniano istniejący porządek gospodarczy, społeczny i polityczny. Deklarowano też kształtowanie "porządku godnościowego” (Röpke, Eucken) lub „porządku gospodarczego według miary człowieka”, mówiąc słowami Müllera-Armacka [1981: 123-140 za Franco 2018: 270].

Antropologiczna koncepcja Wilhelma Röpke zamyka się w obrazie homo liberalis. Jednocześnie pamięta on o omylności człowieka, ale też akcentuje jego wymiar społeczny oraz solidarnościowy i upomina się o indywidualną odpowiedzialność. Broni małych wspólnot i grup pośrednich przed nieuprawnionymi ingerencjami państwa. Humanistyczno-liberalny antropologiczny rdzeń myśli W. Röpke [1964 za Franco 2018: 270] dobrze oddaje zdanie: „miarą gospodarki jest człowiek; miarą

2 Tak rekonstruują myśl Wilhelma Röpke Andrea Hotze i Wolfgang Ockenfels [Hotze 2008: 115-190; Ockenfels 1999: 54]. 
człowieka jest jego stosunek do Boga"’3. U kogoś, kto inspirował się starożytną filozofią, chrześcijańskim obrazem człowieka, tradycją liberalną i chrześcijańską etyką społeczną nie dziwi pozornie szokująca identyfikacja chrześcijanina. Zdaniem Wilhelma Röpke „chrześcijanin jest liberałem, który nie wie, że nim jest” [1949: 18 za Franco 2018: 270].

Całkiem zasadnie umieszcza się tego myśliciela w nurcie gospodarczego personalizmu, a nawet traktuje jako przedstawiciela chrześcijańskiej etyki gospodarczej ${ }^{4}$. Podobnie uważa Chantal Millon-Delsol. Jej zdaniem W. Röpke podjął się zadania dostosowania nauczania społecznego Kościoła do nowoczesnego społeczeństwa [1995: 33]. Z powodzeniem poszukiwał konwergencji między SGR a zasadami chrześcijańskiej etyki społecznej. Jedną z nich jest zasada pomocniczości, której jednak nie da się zrozumieć w izolacji od innych idei przewodnich SGR.

\section{Miejsce pomocniczości wśród idei przewodnich SGR}

Jak sygnalizuje nazwa nurtu filozoficznego, w którym opracowano SGR, jego fundamentem jest idea ordo, czyli ładu, porządku społecznego. Porządek ten musi się opierać na pewnych wartościach podstawowych. Są one wbudowane w cały system, a ich powszechna akceptacja jest przesłanką sprawnego funkcjonowania gospodarki. SGR jest mianowicie syntezą wolności i sprawiedliwości społecznej. Oczywistą konsekwencją wolności jest osobista odpowiedzialność, zaś sprawiedliwości społecznej - solidarność ${ }^{\text {. }}$

Tak jak solidarność poniekąd stoi na straży społecznego wymiaru osoby, broniąc ją przed indywidualizmem, tak pomocniczość broni osobowej wolności, partycypacji i odpowiedzialności przed roszczeniami kolektywizmu. W katolickiej nauce społecznej, która - jak w przypadku W. Röpke - była bliska twórcom SGR, solidarność i pomocniczość są traktowane jako komplementarne względem siebie podstawowe zasady społeczne. Są one dlatego nierozerwalnie ze sobą związane, „ponieważ pomocniczość bez solidarności kończy się partykularyzmem społecznym”, zaś „solidarność bez pomocniczości staje się asystencjalizmem upokarzającym potrzebującego człowieka" - przypomniał Benedykt XVI w encyklice z 2009 r. Caritas in veritate (58).

3 Tak Martin Hoch w laudacji ku czci W. Röpke (w 1962 r.) spuentował jego dorobek.

${ }^{4}$ Tak sądzi m.in. Wolfgang Ockenfels.

${ }^{5}$ Szerzej na ten temat por. Dylus 1994: 11-19, zwłaszcza: 14. 
Jeszcze inne uzasadnienie związku omawianych tu zasad podaje Millon-Delsol. Jak wiadomo, negatywny sens pomocniczości sprowadza się do obowiązku nieingerencji, zaś pozytywny - do obowiązku ingerencji („pomocy”). Ten ostatni znajduje podstawę w idei solidarności. Będąc $z$ natury istotą społeczną, człowiekowi zależy bowiem na wspólnym, a nie tylko indywidualnym dobrobycie [tamże: 34].

Warto przyjrzeć się bliżej subsydiarności, na której bazuje SGR.

\section{Wkład pomocniczości do ładu (ordo) w państwie i społeczeństwie}

Trudno przecenić znaczenie drogowskazu pomocniczości dla ukształtowania właściwej relacji między rynkiem a państwem. Podobnie jak w odniesieniu do obrazu człowieka, ordoliberałowie odcinali się od dwóch ujęć krańcowych: zarówno od klasycznej liberalnej koncepcji państwa „stróża nocnego”, zupełnie nie zainteresowanego rynkiem [por. np. Eucken 1940/1989 za Franco 2018: 273], jak i od różnych form kolektywizmu, gdzie państwo aspiruje do jedynego regulatora stosunków rynkowych. Jak z przekąsem zauważył W. Röpke, w kolektywizmie państwo staje się „,krokodylem” połykającym wszystko wokół [1923/1959: 42-46 za Franco 2018: 273]. W refleksji nad właściwym - z perspektywy kryterium godności osoby i pomocniczości - miejscem państwa w relacji do rynku i zorganizowanego społeczeństwa wiadomo zatem na pewno, że trzeba unikać zarówno rozwiązań na modłę liberalnego państwa minimalnego, jak i tendencji etatystycznych właściwych dla różnych totalitaryzmów.

Generalnie w SGR zakłada się aktywną wobec gospodarki rolę państwa. Koncepcja państwa, które stoi na straży dobra wspólnego jest jego konstytutywnym elementem. Musi mieć ono całościową wizję porządku społeczno-gospodarczego oraz ma czuwać nad jego realizacją. Nie chodzi przy tym o interwencjonizm, o pojedyncze, bezpośrednie ingerencje w czuły mechanizm wolnego rynku. Zadania państwa wobec gospodarki sprowadzają się przede wszystkim do kształtowania ładu (ordo) rynkowego ${ }^{6}$, do budowy "porządku ramowego”, stwarzającego właściwe warunki dla efektywnego funkcjonowania życia gospodarczego. Kryterium prawidłowości tego porządku jest inspiracja do aktywnego uczestnictwa w rynku - tak, aby podejmowanie aktywności gospodarczej okazywało się bardziej atrakcyjne niż zabieganie o środki pochodzące z redystrybucji dochodu społecznego. Wykluczone jest sterowanie procesami gospodarczymi, wymuszone zwykle przez silne grupy

${ }^{6}$ Kompleksową charakterystykę kształtowania się i treści idei ordo w ujęciu Waltera Euckena, twórcy szkoły fryburskiej, przedstawił Grzegorz Szulczewski [2012: 105-131] (zwłaszcza podrozdział 3.3. 
interesu. Państwo ma po prostu stanowić formy porządkujące gospodarkę, ma trafnie ukształtować przedpole rynku?

O podejmowaniu lub niepodejmowaniu określonych zadań przez instytucje państwowe, przez społeczności „większe i wyższe” wobec „mniejszych i niższych" (mówiąc językiem encykliki Quadragesimo anno z 1931 r.) lub przez szczeble decyzyjne „dalsze” i „bliższe” obywatelowi (mówiąc językiem Traktatu z Maastricht z 1992 r.) rozstrzygają kompetencje osoby lub instancji niższego szczebla. Społeczeństwo o rozbudowanej strukturze ciągle musi więc rozstrzygać kwestię podziału kompetencji. Pomocniczość okazuje się tu nieocenionym drogowskazem - zwłaszcza wówczas, gdy dochodzi do konfliktu kompetencji. Nic dziwnego, że nazywa się ją niekiedy „Zasadą kompetencji”. Nie znaczy to wcale, że jest receptą na wszystko. Przedmiotem burzliwych debat od dawna jest chociażby kwestia „kompetencji w zakresie kompetencji”. Wpatrując się w drogowskaz pomocniczości nie ustalimy, kto ma stwierdzać deficyty kompetencji niższej instancji i decydować o przekazaniu zadań instancji wyższej.

Jak wiadomo, kompetencje osób, wspólnot czy decydentów poszczególnych szczebli nie są statyczne, raz na zawsze określone; zmieniają się zależnie od kontekstu. Właśnie dlatego odwołująca się do pomocniczości SGR nie jest sztywną, ustanowioną raz na zawsze doktryną, ale systemem otwartym na zmiany, korekty, reformy. Po okresie narodowosocjalistycznej dyktatury w Niemczech palącym zadaniem było poszukiwanie takiego porządku, który mógłby stanowić przeciwwagę dla potęgi państwa. Dla W. Röpke jego istotnym elementem była kształtująca się oddolnie rozbudowana tkanka społeczna. Mocno akcentował rolę społecznego zaplecza rynku - małych wspólnot, grup pośrednich oraz przeróżnych instytucji. Ich wspieranie oznaczało dla niego afirmację godności człowieka i pozostawało w duchu pomocniczości. Żywe więzi społeczne są bowiem odtrutką na procesy umasowienia i proletaryzacji [Kolev 2013: 119, 154-156, 160-169 za Franco 2018: 273]. Zgodnie z pomocniczością wcale nie wyłącznie państwo, ale właśnie aktorzy indywidualni i społeczni, cały szereg różnych instytucji powołani są do wnoszenia wkładu w gospodarczą i społeczną integrację. Ważne jest zatem uruchomienie takich „sił porządkujących” będących przeciwwagą dla państwa, które są w stanie zahamować koncentrację władzy i powstawanie monopoli. Do takich „sił przeciwdziałających" (Gegenkräfte) zaliczał Röpke m.in. religię, prasę, naukę, rodzinę.

${ }^{7}$ O porządkujących zadaniach państwa społecznego pisałam już wcześniej [por. Dylus 1994: 15].

8 Zwraca na to uwagę m.in. Chantal Millon-Delsol [1995: 33-35]. 
Mają one zabiegać o równowagę między jednostką a społeczeństwem i gwarantować właściwą relację między jednostką a państwem. Mają pomagać obywatelom wieść życie wolne i odpowiedzialne. Do tego samego przyczyniają się nie tylko moralne i intelektualne "siły przeciwdziałające”, ale i materialne - obudowane instytucjami politycznymi i gospodarczymi. Chodzi tu np. o własność prywatną czy gospodarczą niezależność jednostek [Franco 2018: 275].

Kierowanie się pomocniczością przy kształtowaniu państwowego ładu daje ponadto szansę uniknięcia biurokratyzacji, przerostów państwa dobrobytu i koncentracji władzy [Röpke 1950/1964 za Franco 2018: 274]. W. Röpke łączył dalej pomocniczość z filozofią federalizmu i programem decentralizacji [tamże]. W kwestii integracji europejskiej, powołując się na tę zasadę, sprzeciwiał się tworzeniu europejskiego państwa federalnego. Europa jako jedność w wielości ma być raczej zdecentralizowanym związkiem państw Feld 2012: 1-31 za Franco 2018: 274].

\section{Elementy pomocniczości w polityce gospodarczej}

Ordoliberałowie zabiegali o gospodarkę rynkową godną człowieka. Jest ona możliwa, gdy dojdzie do oparcia ustroju gospodarczego na takich wartościach, jak wolność, sprawiedliwość, rozumność. Twórcy SGR, w tym W. Eucken [2005: 231 za Franco: 120], opowiadali się zatem za stworzeniem takiego opartego na wartościach „niezakłóconego ustroju gospodarczego”. Państwo realizujące to zadanie i jego polityka gospodarcza muszą być przy tym pojmowane dynamicznie. Ma to być „silne państwo”: ponadpartyjne i nieprzekupne. Tylko takie będzie w stanie zagwarantować właściwe funkcjonowanie rynkowych „reguł gry” i uczciwej konkurencji oraz zapobiec tendencjom monopolistycznym i koncentracji potęgi gospodarczej, co oznacza eliminację z rynku małych i średnich podmiotów. Tworzenie „systemu konkurencji”, który nie dopuściłby do powstania barier ograniczających dostęp do rynku wielu dynamicznym podmiotom gospodarczym uznawano bodaj za najważniejsze zadanie subsydiarnej polityki gospodarczej. Tendencje monopolistyczne mają być unicestwiane w zarodku, zaś różnorodne kartele i koncerny w interesie pozostałych uczestników rynku winny podlegać kontroli przez jakiś centralny urząd antymonopolowy.

Taka hierarchia zadań w ramach polityki gospodarczej wynikała $z$ doceniania przez ordoliberałów mechanizmu konkurencji jako podstawowego i niezwykle czułego instrumentu rynkowego. Przecież właśnie konkurencja, jak zauważył Franz Böhm, jest siłą rozbijającą potęgę w gospodarce. Pozostawiona samej 
sobie zawiera jednak, według Waltera Euckena, tendencję do samounicestwienia Aby temu zapobiec i nie dopuścić do opanowania rynku przez potężne jednostki gospodarcze, zdolne do wyeliminowania konkurentów oraz do uzyskiwania zysków monopolowych i spekulacyjnych, państwo musi chronić konkurencję.

Poszczególni przedstawiciele szkoły fryburskiej nieco inaczej rozkładali jednak akcenty w sposobie osiągania tego celu. Zdaniem Euckena i Böhma priorytetowa dla państwa jest rola „sędziego pozbawiającego władzy” (entmachtender Schiedsrichter) wielkie kartele. Jak już zaznaczono, ma to czynić poprzez stworzenie efektywnego porządku czy systemu konkurencji. Wprawdzie W. Röpke także akcentował znaczenie instytucjonalnych warunków ramowych dla regulacji porządku konkurencji. Taki porządek gospodarczy uznawał wręcz jako „ramę wartości” dla rynkowej wymiany. Niemniej jednak koncentrował się nie tyle - jak Eucken - na formułowaniu zadań państwa, ale na wypracowaniu kompleksowego politycznego i społecznego „porządku ramowego" dla procesów rynkowych, o czym wspomniano już wcześniej.

Kształtowany polityką gospodarczą "porządek ramowy” gospodarki ma gwarantować bezpośredni dostęp do rynku wszystkim pojedynczym podmiotom gotowym do podjęcia działalności gospodarczej. Ma być przy tym na tyle atrakcyjny, że wyzwoli ich inicjatywę i twórcze możliwości. Na służbie tej idei pozostają bardziej konkretne zadania polityki gospodarczej. Wśród nich na pierwszy plan wysuwa się możliwie pełne zatrudnienie. Zyskuje ono priorytet polityczno-gospodarczy, gdyż większość członków społeczeństwa tylko przez ofertę swej pracy ma szansę stać się aktywnymi uczestnikami rynku. Kategoria uczestnictwa jest zaś kluczowa w rozumieniu pomocniczości. Różne inne przedsięwzięcia polityki gospodarczej, chociażby preferencje kredytowe dla młodych przedsiębiorców: gotowych do podjęcia samodzielnej działalności gospodarczej, prężnych i pełnych inicjatywy, ale nie dysponujących odpowiednim kapitałem, mają na względzie właśnie tę wartość.

Widać z tego, że jednym z najważniejszych celów polityki gospodarczej w systemie SGR jest samodzielność gospodarcza. Chodziło o to, aby - jak to formułował przed laty Ludwig Erhard - maksimum podmiotów przesunąć z obrzeży rynku do jego centrum. Ranga samodzielności jest co najmniej równorzędna innym celom, kojarzonym zazwyczaj z tym systemem, jak chociażby dobrobyt dla wszystkich [Dylus 1994: 15-16]. 
Charakterystyczna dla SGR jest koncepcja „państwa społecznego” (Sozialstaat), które ma prowadzić współzależną z polityką gospodarczą aktywną politykę społeczną [Röpke 1952: 18-27 za Franco 2018: 275]. Wskazane jest, aby w tym miejscu spróbować ustalić, czy i w jaki sposób wyznaczone przez ordoliberałów zarysy ładu społecznego były zgodne z subsydiarnym kierunkowskazem.

\section{Pomocnicza polityka społeczna}

W koncepcji SGR sfera gospodarcza i społeczna tworzą integralną całość. Ordoliberałowie niestrudzenie i dobitnie akcentowali zatem współzależność polityki gospodarczej i społecznej. Warunkiem prawidłowego rozwoju gospodarczego jest odpowiednia polityka społeczna. Z kolei przesłanką właściwej polityki społecznej jest wolna, efektywna gospodarka i porządek rynkowy.

A. Müller-Armack jasno określił cel polityki społecznej. Jest nim integracja człowieka z wolnym porządkiem społeczeństwa. W nieco innym sformułowaniu polityka społeczna ma mieć na uwadze przede wszystkim znalezienie właściwej miary między wzrostem gospodarczym, inicjatywą i wolnością osobistą a równowagą społeczną. Pomoc przy tworzeniu warunków dla godnego życia i bezpieczeństwa socjalnego należy się zwłaszcza tym jednostkom i grupom, które $\mathrm{z}$ różnych względów znalazły się w trudnej sytuacji. Jako taka poniekąd chroni, uzupełnia i koryguje gospodarkę. Nie może jednak przekraczać pewnych granic (właśnie zasada pomocniczości pomaga je wyznaczyć), aby nie zaszkodzić porządkowi rynkowemu [tamże], a w końcu także samym beneficjentom. Na krytykę zasługują mianowicie tak daleko idące interwencje „państwa społecznego”, które destabilizują budżet i powodują wystąpienie takich zjawisk, jak chroniczna inflacja czy „socjalizm fiskalny”, naruszający swobodę dysponowania dochodami przez podatników [Röpke 2009 za: Franco 2018: 276].

W oparciu o fundament efektywnej gospodarki i przy założeniu wzajemnej solidarności obywateli, w ramach polityki społecznej dokonuje się redystrybucja dochodu społecznego. Filarami „państwa społecznego" są przy tym obowiązkowe ubezpieczenia społeczne dla ochrony przed ryzykiem, jakie niesie ze sobą starość, choroba, wypadki, bezrobocie. System emerytalno-rentowy, ubezpieczenia zdrowotnego, wypadkowego i od bezrobocia jest uzupełniony systemem opieki socjalnej i różnymi innymi formami pomocy. Systemy te zasługują na miano pomocniczych wówczas, gdy nie tylko nie ograniczają samodzielności, odpowiedzialności oraz twórczej inicjatywy beneficjentów, ale inspirują i pobudzają ujawnienie się tych cech. Innymi słowy, pomoc świadczona w ramach polityki 
społecznej ma być „pomocą dla samopomocy”. W. Röpke i A. Rüstow postulowali ponadto, aby polityka społeczna była „polityką witalną" (Vitalpolitik), uwzględniającą ramy antropologiczno-społeczne. Ma ona mianowicie zabezpieczać nie tylko materialną egzystencję człowieka, ale i godną pracę, życie rodzinne, właściwą relację do wspólnoty i do przyrody [Röpke 1951: 48-53 za Franco 2018: 276].

Jednocześnie ordoliberałowie zdawali sobie sprawę ze skutków antysubsydiarnej polityki społecznej. Niestrudzenie przestrzegali przed przesadną pomocą i przerostami państwa dobrobytu. Nadmierny interwencjonizm społeczny państwa oznacza bowiem naruszenie równowagi w relacjach między jednostką a społeczeństwem. Często poniża człowieka i czyni zeń kogoś uległego państwu, przyjmującemu formy kolektywistyczne. Grozi też pojawieniem się despotyzmu, centralizacji, biurokracji i korupcji, a także rosnącym wyzyskiem państwa przez grupy interesów. Państwo stopniowo doprowadza do paradoksalnej sytuacji: nikt nie chce ponosić ciężarów, ale wszyscy oczekują od państwa spełnienia wszelkich życzeń i zaspokojenia potrzeb [Röpke 1949: 182-188 za Franco 2018: 276]. Naruszony może zostać wówczas obowiązek osobistej odpowiedzialności, zdolność do samodzielnej troski o siebie i swoich bliskich, zapobiegliwość i oszczędzanie. Twórcy SGR z troską obserwowali bezkrytyczne powierzanie przez ludzi w ręce państwa wszelkich swoich problemów i trosk. Najgroźniejszym społecznie efektem antysubsydiarnej polityki społecznej jest proces kumulacji roszczeń, walka między jednostkami i grupami o maksymalny udział w dzielonych dobrach. Brak stabilizacji politycznej, chwiejność państwa, uleganie naciskom zorganizowanych grup interesu wywołuje bowiem zwykle całą lawinę dalszych żądań, niemożliwych do spełnienia.

Potrzebna jest zatem deetatyzacja polityki społecznej. Subsydiarna pomoc państwa ma jedynie uzupełniać indywidualną zapobiegliwość. Dlatego ordoliberałowie, np. W. Röpke [2009 za Franco 2018: 276], proponowali odtworzenie niektórych instytucji pomocowych znanych z przeszłości: małych wspólnot samopomocowych, grup ubezpieczeń wzajemnych czy kas oszczędnościowo-pożyczkowych. Taka konkretyzacja pomocniczości jest zbieżna ze znanym w katolickiej nauce społecznej skrótowym jej opisem: „tyle społeczeństwa, ile można, tyle państwa ile koniecznie potrzeba". Obok administracji rządowej do jej prowadzenia powinny być mianowicie dopuszczone (a raczej zaproszone) także podmioty pozapaństwowe, składające się na szeroko rozumiane społeczeństwo obywatelskie, jakbyśmy dziś powiedzieli. W dziele łagodzenia kwestii społecznej jest miejsce zarówno dla charyzmatycznych działaczy charytatywnych, jak i dla różnych organizacji 
społecznych, związków, stowarzyszeń, fundacji o zasięgu lokalnym, krajowym, a nawet międzynarodowym, Kościoła nie wyłączając. W każdym razie wielość podmiotów niewątpliwie jest jedną z oznak subsydiarnej polityki społecznej.

Jest nią także decentralizacja tej polityki, za którą zdecydowanie opowiadał się W. Röpke. Łączył tę ideę bezpośrednio z zasadą pomocniczości. Na uwagę zasługuje podana przez niego definicja tej zasady: „oznacza ona, że w obrębie od jednostki do centrali państwowej pierwotne prawo jest udziałem niższego szczebla, zaś wyższy szczebel tylko pomocniczo wkracza w miejsce szczebla usytuowanego bezpośrednio pod nim jedynie wówczas, gdy jakieś zadanie przekracza możliwości tego ostatniego" [tamże: 179 za: Franco 2018: 277]. Współczesną aplikacją tak rozumianej subsydiarnej i zdecentralizowanej polityki społecznej jest pozostawienie w kompetencji samorządów różnych szczebli jak najszerszego zakresu spraw lokalnych ${ }^{9}$ i zapewnienie stabilnych źródeł finansowania wynikających stąd zadań. Jasne określenie kompetencji i odpowiedzialności rządowych oraz samorządowych podmiotów polityki społecznej różnych szczebli pozwoli przy tym uniknąć wielu nieporozumień i konfliktów. Oczywistym uprawnieniem administracji rządowej jest kontrola legalności działania samorządów. Z kolei uprawnieniem obywateli i ich organizacji jest współudział w projektowaniu kierunków rozwoju polityki społecznej. Tak rozumiana decentralizacja umacnia podmiotowość obywateli zwiększa ich udział w sprawowaniu władzy. Jest solidnym fundamentem silnego i sprawnego państwa. Natomiast sprzeczna z pomocniczością, niczym nieuzasadniona centralizacja polityki społecznej, powodująca utratę ludzkich energii, wyzwalająca bierność i sfrustrowanie społeczeństwa, zazwyczaj dodatkowo wiąże się, jak zauważył Jan Paweł II, z dominacją „logiki biurokratycznej” (Centesimus annus, 48), z przerostem nadzoru i kontroli ${ }^{10}$.

Dokonana tu syntetyczna charakterystyka pomocniczej polityki społecznej w ramach koncepcji SGR uprawnia do wniosku, że w literaturze przedmiotu ten model jej uprawiania słusznie nazwano „modelem motywacyjnym”"1. Punktem wyjścia tego modelu polityki społecznej jest bowiem założenie samodzielnego zaspokajania potrzeb obywateli dzięki wynagrodzeniu za pracę. Świadczona pomoc nie jest celem, lecz środkiem motywującym do przezwyciężenia trudnej sytuacji.

\footnotetext{
9 W obszarze polityki społecznej zadania samorządu obejmują: ochronę zdrowia, pomoc społeczną, komunalne budownictwo mieszkaniowe, oświatę, kulturę, opiekę nad kobietami w ciąży [Auleytner 1997: 313].

${ }_{10}$ Szerzej na ten temat por. Dylus, Mazur 2018: 546-549.

${ }^{11}$ Syntetyczna charakterystyka tego modelu (i innych) - por. Balicki 2004: 893-894.
} 


\section{Aktualność pomocniczości jako idei przewodniej SGR}

Warto najpierw przypomnieć, że u ordoliberałów znajdujemy zalążki idei społeczeństwa obywatelskiego. Niewątpliwie jej renesans, wraz z odkryciem znaczenia kapitału społecznego nastąpił później. Po upływie kilku dekad od wdrożenia subsydiarnego systemu SGR tym bardziej jesteśmy przekonani, że dla przezwyciężenia pojawiających się dziś nowych kwestii społecznych znaczenie trzeciego sektora jest trudne do przecenienia. Również Benedykt XVI przypomniał (por. Caritas in veritate, 37-39), że tkwi w nim ogromny potencjal. Wprowadza on mianowicie do sfery publicznej element absolutnie niezbędny dla prawidłowego funkcjonowania i gospodarki, i polityki. Chodzi tu o darmowość i bezinteresowność, czyli „logikę daru”, wykraczającą poza „logikę rynkową" i „logikę polityczną”.

Jedną z wielu nowych kwestii społecznych, szczególnie palących w świecie zachodnim, także w starzejącej się „babci Europie” (jak określił nasz kontynent papież Franciszek) jest chociażby właściwy sposób organizacji opieki nad obłożnie chory$\mathrm{mi}^{12}$. Nie rozwiąże się dobrze tego problemu właśnie bez pomocniczej polityki społecznej. Wymaga ona w tym przypadku stworzenia całego „rusztowania struktury socjalnej”. Wymaga współpracy i podziału zadań między publiczne i pozapaństwowe podmioty opiekuńcze: prywatne i pozarządowe [por. WelskopDeffaa 2018: 15].

W Polsce zainteresowanie zasadą pomocniczości jako ideą przewodnią organizacji życia społecznego wyraźnie ożywiło się po roku 1989. W okresie transformacji ustrojowej na nowo odkryto ten drogowskaz, wiarygodnie pokazujący kierunki reform. O zafascynowaniu pomocniczością, decentralizacją, „państwem obywatelskim" przy koncypowaniu i realizacji reformy samorządowej piszą wprost jej twórcy: Michał Kulesza [2018: 129-136] i Jerzy Rogulski [2007: 32-35]. Uchwalona 2 kwietnia 1997 r. Konstytucja RP stanowi (w preambule), że prawa podstawowe mają być oparte na „zasadzie pomocniczości umacniającej uprawnienia obywateli i ich wspólnot”. Charakterystyczny dla poprzedniego ustroju scentralizowany system paternalizmu państwowego w dystrybucji świadczeń socjalnych nie był już możliwy. W duchu pomocniczości pozostawała natomiast decentralizacja polityki społecznej. Była ona możliwa na skutek stworzenia nowej demokratycznej

${ }^{12}$ Właśnie temu zagadnieniu został poświęcony wydawany przez Katolicką Centralę Nauk Społecznych w Mönchengladbach jeden z ostatnich numerów serii zeszytów „Kościół i społeczeństwo". W każdym numerze próbuje się artykułować jakąś palącą kwestię. Tym razem tytuł zeszytu brzmi alarmująco: „Zakończyć wyzysk w tak zwanej opiece 24-godzinnej! Uwagi etyczne do stosunków pracy w niemieckiej opiece domowej” [por. Emunds 2018]. 
instytucji zastępującej państwo na szczeblu lokalnym, czyli samorządu terytorialnego. Poza tym po 1989 r. do realizacji polityki społecznej dopuszczono podmioty pozapaństwowe, czyli organizacje pozarządowe, związkowe, fundacje, stowarzyszenia, w tym - podmioty wyznaniowe. Wiemy także, że w art. 20 ustawy zasadniczej postanowiono: „społeczna gospodarka rynkowa stanowi podstawę ustroju gospodarczego Rzeczypospolitej Polskiej”. Zdecydowanie sprzyja to przestawieniu polityki gospodarczej i społecznej na tory subsydiarne. Inną sprawą, wymagającą odrębnego namysłu jest już faktyczna realizacja tej konstytucyjnej normy ${ }^{13}$.

Z drugiej jednak strony rzetelna refleksja nad aktualnością pomocniczości nie może tracić z pola widzenia pewnych niepokojących symptomów. Otóż wydaje się, że w drugiej dekadzie XXI wieku nie ma wielkiego zapotrzebowania na pomocniczość. Dominuje raczej antysubsydiarny duch czasu. Wobec odczuwanych do dziś skutków kryzysu finansowego i gospodarczego z 2008 r. i lat następnych, niepokojących konsekwencji globalizacji, kryzysu migracyjnego oraz symptomów deglobalizacji, wśród obywateli państw świata zachodniego szerzy się wrażenie narastającego chaosu. Jak zauważył Udo Di Fabio [2018], „Przez zachodnie demokracje przebiega nowe rozdarcie, wieje porywisty wiatr populizmu, następuje rebelia przeciw zimnym warunkom zglobalizowanej gospodarki oraz twardej logice ponadpaństwowego rządzenia”. W 2020 r. dodatkowo cały świat został dotknięty pandemią koronawirusa. Jej zgubne gospodarcze i społeczne konsekwencje są trudne do oszacowania. Już dziś widać jednak, że w tej atmosferze rodzą się tęsknoty za paternalistycznym państwem z autorytarną władzą, która „zaprowadziłaby porządek”. Tendencje etatystyczne są poniekąd zrozumiałe w warunkach wielorakich zagrożeń i związanego z nim niepokoju, ale taki duch czasu zdecydowanie nie sprzyja pomocniczości. Niemniej właśnie w tym kontekście - jak się wydaje - tym bardziej należy dziś przypominać porządkujący potencjał zasady pomocniczości.

${ }^{13} \mathrm{Na}$ ten temat por. np. Społeczna gospodarka rynkowa w Polsce. Postulat czy rzeczywistość? (2015); Dylus 2016: 333-350, (zwłaszcza podrozdział V.3: „Społeczna gospodarka rynkowa jako podstawa ustroju gospodarczego Polski”). O subsydiarnej polityce społecznej w III RP por. Dylus, Mazur 2018: 555-558. 


\section{Bibliografia}

Auleytner J. (1997), Polityka społeczna. Teoria a praktyka, Wyższa Szkoła Pedagogiczna TWP, Warszawa.

Balicki J. (2004), Polityka społeczna, w: Szlachta B. (red.), Słownik społeczny, Wydawnictwo WAM, Kraków.

Delsol C. (1995), Zasada pomocniczości, Wyd. Znak, Kraków.

Delsol C. (1996), Zasada subsydiarności - założenia, geneza oraz problemy współczesne, w: Milczarek D., (red.), Subsydiarność, Dom Wydawniczy „Elipsa”, Warszawa.

Di Fabio U. (2018), Berlin ist nicht Weimar, „Frankfurter Allgemeine Zeitung“ 27 września 2018 (Nr. 225).

Dylus A. (1994), Gospodarka, moralność, chrześcijaństwo, Wyd. Fundacji ATK Kontrast, Warszawa.

Dylus A. (2016), Polityka w perspektywie etycznej i religijnej, Wyd. UKSW, Warszawa.

Dylus A., Mazur J. (2018), Pomocniczość, dobro wspólne i solidaryzm jako aksjologiczne determinanty polskiej polityki społecznej, w: Bojanowska E., Grewiński M., Rymsza M., Uścińska G. (red), Stulecie polskiej polityki społecznej 1918-2018, Wyd. Ministerstwo Rodziny, Pracy i Polityki Społecznej, Narodowe Centrum Kultury, Warszawa.

Emunds B. (2018), Beendet die Ausbeutung in der sogenannten 24-Stunden-Pflege Ethische Bemerkungen zu Arbeitsverhältnissen in deutschen Pflegehaushalten, J.P. Bachem Medien, „Kirche und Gesellschaft“ Nr. 45, Köln.

Eucken W. (1940/1989), Die Grundlagen der Nationalökonomie, Berlin, w: Eucken W. (1952/2004), Grundsätze der Wirtschaftspolitik, Tübingen.

Eucken W. (2005), Podstawy polityki gospodarczej, Wydawnictwo Poznańskie, Poznań.

Feld L. (2012), Europa in der Welt von heute: Wilhelm Röpke und die Zukunft der Europäischen Währungsunion, „Hamburgisches WeltWirtschaftsInstitut” 2012 Bd. 70.

Fel S. (red.) (2015), Społeczna gospodarka rynkowa w Polsce. Postulat czy rzeczywistość?, Wyd. KUL, Lublin.

Franco G. (2018), Wilhelm Röpkes Beitrag zur Sozialen Marktwirtschaft, „Die neue Ordnung" $2018 \mathrm{Nr} .4$.

Hotze A. (2008), Menschenbild und Ordnung der Sozialen Marktwirtschaft. A. Rüstow, W. Röpke, A. Müller-Armack und ihre Konzeption einer Wirtschafts- und Gesellschaftsordnung nach dem „Maße des Menschen“, Hamburg.

Kolev S. (2013), Neoliberale Staatsverständnisse im Vergleich, Stuttgart 2013.

Kulesza M. (2008), Budowanie samorzadu, Wydawnictwo MUNICIPIUM S.A., Warszawa 2008.

Kulesza M. (2008), Zasada subsydiarności jako klucz do reform ustroju administracyjnego państw Europy Centralnej i Wschodniej (na przykładzie Polski), w: Subsydiarność, Dom Wydawniczy „Elipsa”, Warszawa.

Müller-Armack A. (1981), Der Moralist und der Ökonom. Zur Frage der Humanisierung der Wirtschaft, w: tenże, Genealogie der Sozialen Marktwirtschaft. Frühschriften und weiterführende Konzepte, Bern - Stuttgart.

Nothelle-Wildfeuer U. (2004), Soziale Marktwirtschaft als subsidiaritätsbasierte Marktwirtschaft, w: Goldschmidt N., Wohlgemuth M. (red.), Die Zukunft der 
Sozialen Marktwirtschaft. Untersuchungen zur Ordnungstheorie und Ordnungspolitik, Tübingen.

Ockenfels W. (1999), Wilhelm Röpke als christlicher Wirtschaftsethiker, „Ordo - Jahrbuch für die Ordnung von Wirtschaft und Gesellschaft", Bd. 50.

Regulski J. (2007), Reformowanie państwa. Moje doświadczenia, Wydawnictwo Wyższej Szkoły Administracji Publicznej w Szczecinie, Szczecin.

Röpke W. (1949), Civitas humana. Grundfragen der Gesellschafts- und Wirtschaftsreform, Erlenbach-Zürich.

Röpke W. (1950/1964), Die Enzyklika "Mater et Magistra" in marktwirtschaftlicher Sicht, w: Röpke W. (1950/1964), Wort und Wirkung, Ludwigsburg.

Röpke W. (1937/1979), Die Lehre der Wirtschaft, Bern - Stuttgart 1937/1979.

Röpke W. (2009), Jenseits von Angebot und Nachfrage, Düsseldorf.Röpke W. (1950), Maß und Mitte, Erlenbach-Zürich.

Röpke W. (1957/1964), Marktwirtschaft ist nicht genug, w: Röpke W. (1957/1964), Wort und Wirkung, Ludwigsburg.

Röpke W. (1952), Sozialpolitik einer freien Gesellschaft, w: Diskussion über eine bessere Sozialpolitik, Hrsg. G. Duttweiler, St. Gallen.

Röpke W. (1951), Sozialpolitik einer freien Gesellschaft, w: Röpke W. (1951), Liberale Sozialpolitik, „Der Volkswirt“ $1951 \mathrm{nr}$ 51-52/5.

Röpke W. (1950/1964), Wesen und Wandel der Gesellschaft, w: Röpke W. (1950/1964), Wort und Wirkung, Ludwigsburg.

Röpke W. (1923/1959), Wirtschaftlicher Liberalismus und Staatsgedanke, w: Röpke W. (1923/1959), Gegen die Brandung, Erlenbach-Zürich - Stuttgart.

Szulczewski G. (2012), Rozważania o miejscu etyki i moralności w teorii i praktyce gospodarczej, Oficyna Wydawnicza SGH w Warszawie, Warszawa.

Welskop-Deffaa E. M. (2018), Das Soziale in der digitalen Marktwirtschaft, J.P. Bachem Medien, „Kirche und Gesellschaft“ Nr. 447, Köln. 